\title{
Can the Bank's Intermediation Function be a Mediator between Third-Party Funds and Non-Performing Financing on The Profitability of Islamic Commercial Banks in Indonesia?
}

\author{
$1^{\text {st }}$ Novi Mubyarto ${ }^{1}, 2^{\text {nd }}$ Khairiyani Khairiyani ${ }^{2}, 3^{\text {rd }}$ Kurniyati Kurniyati $^{3}$ \\ \{novimubyarto@uinjambi.ac.id ${ }^{1}$, khairiyani@uinjambi.ac.id ${ }^{2}$, nianawawi54@gmail.com ${ }^{3}$ \} \\ UIN Sulthan Thaha Saifuddin Jambi $i^{1,2,3}$
}

\begin{abstract}
The purpose of this research is to examine whether the bank's intermediation function can become a mediator between third-party funds and non-performing financing on the profitability of Islamic commercial banks in Indonesia. In addition, this research also examines the direct influence of third-party funds and non-performing financing on the intermediation function and profitability. Using time-series data for the period January 2013 to February 2021, with purposive sampling technique. The analytical method used is path analysis, with the Bootstrapping technique. The results of the research show that the intermediation function has not been able to significantly mediate third-party funds and non-performing financing on profitability. Meanwhile, the direct effect of third-party funds and non-performing financing on the intermediation function is significant. As for the direct influence between third-party funds, non-performing financing, and the intermediation function on profitability, only third-party funds, and non-performing financing are significant.
\end{abstract}

Keywords: Intermediation Function, Profitability, Third-Party Funds, Non-Performing Financing, Islamic Commercial Banks, Indonesia.

\section{Introduction}

The economic development of a country is closely related to banking performance. This is inseparable from the main function carried out by the banking sector, namely as a financial intermediary institution [1]. The banking sector has an important role in achieving strong incentives for investment, providing broad access to assets and markets, and ultimately reducing risks and vulnerabilities [2]. A well-run intermediation function will create optimal and efficient use of funds. This will certainly have an impact on increasing productive activities from loaned funds so that the output of production activities will increase, and new jobs that have sprung up increase the level of prosperity and welfare of the community [3].

The intermediation function can also be used as an indicator to measure the level of bank expansiveness in lending or financing, as well as the level of banking efficiency, where bank efficiency is one of the indicators to analyze the performance of a bank, and also as a means to further increase the effectiveness of the monetary policy [4]. The large portion of the financing provided is a representation of the banking intermediation function. Or in other words, the 
amount of financing provided by a bank can show the ability of the bank in its role as a financial intermediary [5].

The effectiveness of banking in carrying out the intermediation function in Islamic banks can be measured through the Financing to Deposit Ratio (FDR). This ratio is a comparison between the amount of financing disbursed by the bank to the number of funds raised from the Third-Party Fund (TPF). This indicator is a measure of the level of the expansiveness of banks in disbursing financing. The higher this indicator, the better the bank will perform its intermediation function, and vice versa [6]. Therefore, in this study, the intermediation function is proxied by FDR.

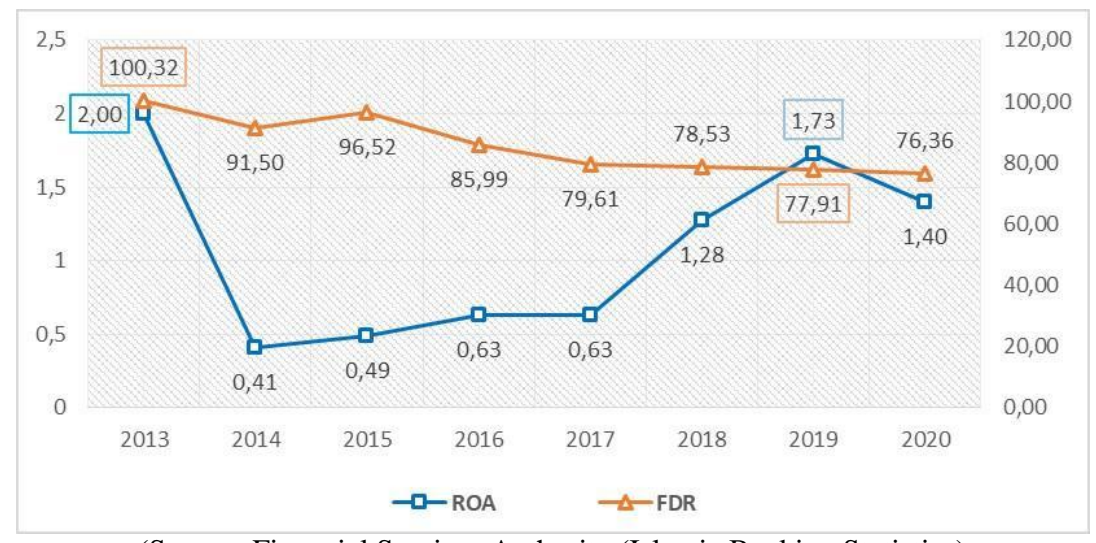

(Source: Financial Services Authority (Islamic Banking Statistics)

Fig. 1. Development of Financing to Deposit Ratio (FDR) and Return on Assets (ROA) of Islamic Commercial Banks in Indonesia Period 2013 - 2020 (percent).

Based on Fig 1, shows that the development of FDR value in 2013 was $100.32 \%$ or within the ideal standard set by Bank Indonesia (BI), which is $80 \%$ to $110 \%$ [7]. The high FDR value indicates that the performance of the BUS in performing its intermediation function is getting better [8]. However, in 2014 there was a decrease to $91.50 \%$ and slightly improved to $96.52 \%$ in 2015. Despite the decline, the FDR value was still at BI standards. This means that the performance of BUS financing in carrying out its intermediation function is still in good condition, and the quality of liquidity is also quite adequate. The minimum requirements are met, but there are still some weaknesses that require management attention [8].

In the following period, there was a significant decline from $85.99 \%$ in 2016 , to $76.36 \%$ in 2020. This value is already below the ideal standard value set by Bank Indonesia, which is $80 \%$ to $110 \%$. This shows that during this period the performance of BUS in Indonesia was increasingly less effective in carrying out its intermediation function. According to Yuwono and Meiranto, one of the factors that affect the ability of banks to carry out their intermediation function is Third-Party Funds (TPF) [9]. The amount of TPF is a surplus of public funds that are stored in the form of demand deposits, savings, time deposits, and other equivalent forms [10]. If the condition of TPF is stable, it will be able to provide a level of certainty in lending decisions. This means that the increase in third-party funds has a positive effect on lending by banks [11].

The behavior of offering credit or bank financing, apart from being influenced by the availability of funds sourced from TPF, is also influenced by the soundness of the banking 
system itself, such as the number of non-performing loans (NPL) [12]. In this study, the risk in channeling bank funds to customers is proxied through Non-Performing Financing (NPF). The higher the NPF ratio, meaning the higher the level of financing risk that will be borne by the bank. The results of the study by Somantri and Sukmana found that the level of non-performing financing had a negative and significant influence on bank intermediation function [13]. Likewise Erfina and Sari, also stated that TPF and NPF had a significant effect on FDR [14].

The higher the FDR ratio indicates that the distribution of funds for financing is getting bigger so that these types of financing it is expected to increase the profitability of Islamic banks [15]. Setiawan and Indriani stated that financing is the main factor that can affect the level of bank profitability [16]. Most of the bank's source of income comes from the contribution of financing distribution [17]. Profits followed by an increase in profitability indicators are a measure of the success of banking operations. One of the profitability ratios is the return on assets (ratio $R O A$ ). This ratio is used to assess financial compensation for the use of assets to net income (earnings after interest and taxes) [18]. In other words, the ROA ratio is used to measure how much net profit will be generated from each rupiah of funds embedded in total assets.

A high percentage of profitability ratio (ROA) indicates that the company can manage its assets efficiently. When viewed from the ROA value as a proxy for profitability in Graph 1.1 above, it shows that the rate of return on BUS assets in 2013 was $2.0 \%$, this value indicates that the bank can use its assets or assets to generate profits or profits optimally. . However, this capability decreased significantly to $0.41 \%$ in 2014 . In the next period, the performance of BUS slowly began to improve slightly from year to year to $0.73 \%$ in 2019 . This indicates that earning assets, especially the financing portfolio, have gradually been able to provide value for banking operations. However, this condition did not last long, and again slowed down to $1.40 \%$ in 2020 . This value when referring to Bank Indonesia (BI) standards is in a non-ideal condition, where the best ROA standard is at least $1.5 \%$ [19]. This means that for several periods there has been a decline in profit followed by a decrease in profitability indicators, which indicates the deteriorating performance of banking operations.

The ability of a bank to generate profit is determined by the amount of financing disbursed, it is also determined by the availability of funds sourced from Third-Party Funds (TPF) [16]. The increase in the number of deposits that banks have successfully collected will be balanced by increasing the amount of financing (FDR) so that the assets owned by banks become productive and generate profits [16]. Therefore, in this study, financing as an intermediation function (FDR) is used as a mediator variable, namely the transmission line between ThirdParty Funds (TPF) and bank profitability (ROA). As the main activity in generating profit, financing activities also have the potential to provide the greatest risk to banks [4]. According to Setiawan and Indriani, the level of non-performing financing (NPF) is also a factor that can affect profitability [16]. The higher the NPF value reflects the deteriorating quality of bank financing, this condition causes the number of non-performing loans to increase. This will have an impact on the reduced profitability of the bank, as a result of uncollectible funds, and also cause the loss of opportunities to obtain additional income, because the bank cannot finance other productive assets [20]. This means that an increase in NPF can have a direct effect on profitability, and can also have an indirect effect through financing like a bank intermediation function (FDR).

Based on the phenomena described above, it raises the interest of researchers to conduct a more in-depth analysis of the transmission line between Third-Party Funds (TPF) and the level of non-performing financing (NPF) on the intermediation function (FDR) and profitability (ROA) at Islamic Commercial Banks in Indonesia. Indonesia. 


\section{Methodology}

This research uses secondary data, which was obtained from the Website of the Financial Services Authority (OJK), regarding Sharia Banking Statistics (SPS) for various periods. This type of research is explanatory research which aims to test a hypothesis obtained from a particular theory to confirm or strengthen the hypothesis, as well as develop theories and hypotheses from various existing research results. The focus of this study is to predict and analyze the indirect effect of third-party funds (TPF) and non-performing financing (NPF) on profitability, through the intermediation function as a variable intervening. In addition, an analysis of the direct influence of Third-Party Funds (TPF) and non-performing financing (NPF) will also be carried out on the intermediation function and profitability.

Determination of the number of samples in this study using the purposive sampling method, namely the technique of determining the sample with certain considerations. Using time-series data for the period January 2013 to February 2021, or 98 months. The analytical method used was path analysis, with Mechanical Bootsrapping by PLS, using the help of Software Statistical Product and Service Solutions (SPSS) version 22 combined with HayesmacrosSoftware [21]. The method of path analysis used in this study refers to the concept of theory and studies The empirical data that has been described previously, namely that Third-Party Funds (TPF) and non-performing financing (NPF) have a direct effect on the intermediation function (FDR) and profitability (ROA). It also has an indirect effect on profitability, through the intermediation function as a variable intervening.

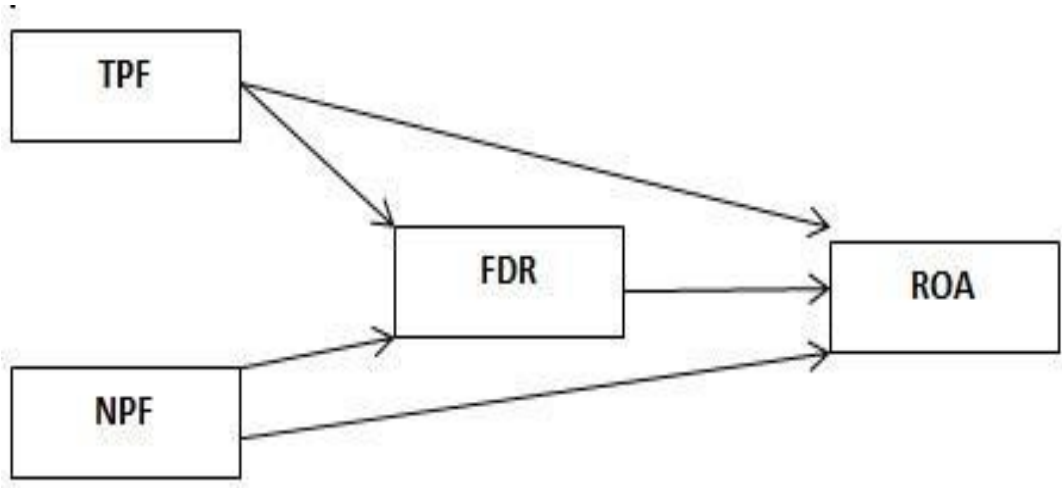

Fig. 2. Research Framework "The analysis of mediator factors".

The Double-Log Regression Equationwith Path Analysis Method used is:

$$
\begin{aligned}
& \operatorname{LogFDR}_{t}=\alpha_{2}+\beta_{2} \operatorname{LogTPF}_{t}+\beta_{3} \operatorname{LogNPF}_{t}+\varepsilon_{2} \\
& \operatorname{LogROA}_{t}=\alpha_{1}+\beta_{1} \operatorname{LogTPF}_{t}+\beta_{4} \operatorname{LogNPF}_{t}+\beta_{5} \operatorname{LogFDR}_{t}+\varepsilon_{1}
\end{aligned}
$$

Description:

$\alpha$ is a constant (intercept); $\beta$ is the coefficient (slope); $\mathrm{t}$ is time; $\varepsilon$ is the error term. 


\section{Result and Discussion}

The following will show the results of research on the transmission lines of direct and indirect effects, between Third-Party Funds and Non-performing Financing on the Intermediation Function and Profitability. Namely as follows:

\subsection{The Direct Effect of Third-Party Funds and Non-performing Financing on the Bank's Intermediation Function.}

To prove the research hypothesis, which states that there is a direct influence between Third-Party Funds (TPF) and non-performing financing on the intermediation function, either partially or simultaneously, the results are as shown in Table 1 and Table 2, as follows:

Table 1. Value of Coefficient of Determination and F Test Results The Direct Effect of Third- Party Funds and Non-performing Financing on the Intermediation Function.

\begin{tabular}{|ccccccc|}
\hline $\mathbf{R}$ & $\mathbf{R}-\mathbf{s q}$ & Adj R-sq & $\mathbf{F}$ & df1 & df2 & p \\
\hline, 8868 &, 7865 &, 7820 & 174,9654 & 2,0000 & 95,0000 &, 0000 \\
\hline
\end{tabular}

Based on estimates in Table 1, for the equation (1), it appears that the value of the coefficient of determination (Adj R -square) of 0.7920 , which means that $79.20 \%$ of the variation in changes in the Bank's Intermediation Function can be explained by variations in changes in the variables of Third-Party Funds and Non-performing Financing. Meanwhile, the remaining $20.80 \%$ is explained by other variables, outside the model.

Furthermore, the obtained F-count value of 174.9654 with a probability of 0.0000 or significant at $95 \%$ alpha ( $\mathrm{sig}<0.05$ ). So it can be concluded that there is a joint influence between Third-Party Funds and Non-performing Financing on the Bank's Intermediation Function.

Table 2. Results of t-test estimation of the direct effect of third-party funds and non-performing financing on the intermediation function.

\begin{tabular}{|ccccc|}
\hline & Coeff. & s.e. & t & p \\
\hline Constant & 4,2700 &, 1248 & 34,2216 &, 0000 \\
\hline LOGTPF &,- 4220 &, 0228 & $-18,5034$ &, 0000 \\
\hline LOGNPF &,- 1326 &, 0219 & $-6,0429$ &, 0000 \\
\hline
\end{tabular}

\subsubsection{Direct Effect of Third-Party Funds on the Intermediation Function.}

The results of the t-test in Table 2, for the Third-Party Fund variable, are -18.5034 with a probability value of 0.0000 or significant at $95 \%$ alpha ( $\mathrm{sig}<0.05)$. This means that the third-party funds that have been collected by the bank, have a significant direct effect on the bank's intermediation function. The elasticity coefficient value is -.4220 , meaning that every $1 \%$ increase in third-party funds will cause a significant decrease in the bank's intermediation function by $0.42 \%$, assuming other variables are constant. Or in other words, the amount of financing disbursed to the community has decreased, in line with the increase 
in third-party funds (savings, demand deposits, and time deposits) that were successfully collected by banks.

The results of this study contradict the hypothesis, which states that Third-Party Funds (TPF) have a significant positive effect on the Bank's Intermediation Function (FDR). However, this finding is in line with the results of a study from Fitri Astuti, which states that Third-Party Funds have a negative and significant effect on the Intermediation Function. This can happen because the Bank has additional alternatives in managing its investment funds, one of which is placing these funds in other productive assets. If this is done, then third-party funds will increase, but the distribution of bank financing will decrease [22].

The high growth of third-party funds and the low rate of credit growth can occur under certain conditions, where people prefer to save their income as a precaution rather than for investment or consumption. This can cause the growth rate of deposits to be higher than credit growth [23]. Bank Indonesia (BI) explained that bank credit slowed down due to limited economic activity, and banks' prudence in lending [24]. The intermediation function of the financial sector remains weak due to limited credit growth in line with subdued domestic demand due to depressed corporate performance and prudent banking practices [25].

\subsubsection{Direct Influence of Troubled Financing on the Intermediation Function.}

Furthermore, for the estimation results of the direct effect of non-performing financing on the intermediation function, based on the t-test in Table 2, the results show that the $\mathrm{t}$ count value is -6.0429 with a probability value of 0.0000 or significant at $95 \%$ alpha ( $\mathrm{sig}<$ $0,05)$. This means that non-performing financing has a significant direct effect on the intermediation function. The elasticity coefficient value is -.1326 , meaning that every $1 \%$ increase in non-performing financing will cause a significant decrease in the bank's intermediation function by $0.13 \%$, assuming caters paribus. The results of this study support the results of previous studies by Somantri and Sukmana, who found that the level of nonperforming financing (NPF) had a negative and significant effect on the bank intermediation function (FDR). The results of this study are also consistent with the research hypothesis, namely the level of non-performing financing has a direct and significant negative effect on the bank's intermediation function.

\subsection{Direct Effects of Third-Party Funds, Non-performing Financing, and Intermediation Functions on Profitability.}

To prove the research hypothesis, which states that there is a direct influence between Third-Party Funds, non-performing financing, and the intermediation function on profitability, both partially and simultaneously, it can be seen in Table 3 and Table 4, as follows:

Table 3. Value of Coefficient of Determination (Adj R-sq) and F Test Results from Direct Effects of ThirdParty Funds, Non-performing Financing, and Intermediation Functions on Profitability.

\begin{tabular}{|lllcccc|}
\hline $\mathbf{R}$ & $\mathbf{R}-\mathbf{s q}$ & adj R-sq & $\mathbf{F}$ & $\mathbf{d f 1}$ & $\mathbf{d f 2}$ & $\mathbf{p}$ \\
\hline, 6425 &, 4127 &, 3940 & 22,0222 & 3,0000 & 94,0000 &, 0000 \\
\hline
\end{tabular}

Based on the estimation results in Table 3, for the regression equation (20), the value of the coefficient of determination (Adj R -square) of 0.3940 , which means that $39.40 \%$ variations in 
changes in the level of profitability (ROA) of banks can be explained by variations in changes in the variables of Third-Party Funds (TPF), Non-performing Financing (NPF), and Intermediation Functions (FDR). Meanwhile, the remaining $60.60 \%$ is explained by other variables, outside the model.

Based on the estimation results, the F-count value is 22.0222 with a probability value of 0.0000 or significant at $95 \%$ alpha $(\mathrm{sig}<0.05)$. So it can be concluded, that Third-Party Funds (TPF), Non-performing Financing (NPF), and the Intermediation Function (FDR), together have a significant effect on Profitability (ROA). This finding supports the results of a study by Sari and Murni, which stated that variables of Third-Party Funds (TPF), non-performing financing (FDR), and loan to deposit ratio (LDR) simultaneously have a significant effect on return on assets (ROA) [26].

Table 4. Results of t-test estimation of the direct influence of third-party funds, non-performing financing, and the intermediation function on profitability.

\begin{tabular}{|lcccc|}
\hline & Coeff. & s.e. & t & p \\
\hline Constant & $-4,9072$ & 4,3682 & $-1,1234$ &, 2641 \\
\hline LOGFDR &, 5956 &, 9839 &, 6053 &, 5464 \\
\hline LOGTPF &, 8653 &, 4693 & 1,8438 &, 0684 \\
\hline LOGNPF & $-1,3877$ &, 2475 & $-5,6071$ &, 0000 \\
\hline
\end{tabular}

Next, to partially determine the effect of independent variables on profitability, it can be seen based on the t-test, in Table 4.

\subsubsection{The direct influence of the intermediation function on profitability.}

The results of the t-test in Table 4, for the Intermediation Function variable, are 0.6053 with a probability value of 0.5464 , or not significant at $95 \%$ alpha ( $\mathrm{sig}>0.05)$. This means that the intermediation function (FDR) has no significant effect on profitability (ROA). Or in other words, financing distribution activities have not been able to contribute to generating a significant level of profit for banks. Furthermore, the value of the elasticity coefficient which is positive at 0.5956 indicates that the increase in financing distribution activities as a bank intermediation function is directly proportional to the level of profitability. This condition indicates that the quality of financing disbursed is still less effective, so it has not had a significant impact on increasing profits for banks. The results of this study contradict the previous hypothesis, which states that the distribution of financing as a function of bank intermediation has a positive and significant effect on profitability.

\subsubsection{Direct Effect of Third-Party Funds on Profitability}

The results of the t-test for the TPF variable are 1.8438 with a probability value of 0.0684 or significant at $90 \%$ alpha $(\mathrm{sig}<0.10)$. This means that the third-party funds that have been collected have a direct positive and significant effect on profitability. The elasticity coefficient value is 0.8653 , meaning that, every $1 \%$ increase in third-party funds, will cause an increase in bank profitability by $0.87 \%$, assuming caters paribus. This finding supports the hypothesis, which states that Third-Party Funds (TPF) have a positive and significant effect on profitability (ROA). Several studies have shown that there is a 
significant effect between TPF on ROA [27]. This is also following the results of research from Dawood, which states that Third-Party Funds (TPF) have a positive and significant effect on profitability (ROA) [28]. Likewise, the results of a study by Wibisono and Wahyuni also stated the same thing [29].

\subsubsection{The Direct Effect of Problem Financing on Profitability.}

The results of the t-test for the NPF variable are -5.6071 with a probability value of 0.0000 or significant at $95 \%$ alpha $(\mathrm{sig}<0.05)$. This means that non-performing financing has a significant direct effect on profitability. The value of the elasticity coefficient is 1.3877 , meaning that every $1 \%$ increase in the number of non-performing financing will cause a decrease in bank profitability by $1.39 \%$ assuming other variables are constant (caters paribus). The increase in non-performing financing (NPF) experienced, resulted in banks losing their ability to generate optimum profits from these main activities. The results of this study support the hypothesis, which states that non-performing financing has a significant negative effect on profitability. The results of this study also support the results of a study by Putrianingsih and Yulianto, who stated that Non-Performing Loans (NPLs) had a negative and significant effect on profitability (ROA) [30]. From these results, it can be interpreted that the increase and decrease in the number of non-performing financing (NPF), which consists of current, substandard, doubtful, and non-performing financing can significantly affect the profitability of the bank [31].

Based on these findings, Ubaidillah stated that an increase in non-performing financing as seen from the NPF ratio will harm the performance of Islamic banking. One of the dangers of non-performing financing is the non-payment of financing that has been distributed to the community, either partially or completely. The increase in the ratio of non-performing loans to banks will affect the level of operational soundness, quality of financing, and soundness of banks. This condition will then have an impact on the level of financial liquidity and solvency, which in turn will affect the level of trust of customers or the public [32].

\subsection{Indirect Effect of Third-Party Funds and Non-performing Financing on Profitability Through the Intermediation Function.}

To test the transmission path of the indirect effect of Third-Party Funds and Nonperforming Financing variables on Profitability through the Intermediation Function as a mediator or intervening variable, it can be seen in Table 5, as follows:

Table 5. Estimation Results of the Indirect Effect of Third-Party Funds and Non-Performing Financing on Profitability Through the Intermediation Function as a Mediator.

\begin{tabular}{|lcccc|}
\hline & Effect & SE(boot) & LLCI & ULCI \\
\hline LOGTPF &,- 2513 &, 2429 &,- 7041 &, 2974 \\
LOGNPF &,- 0789 &, 0774 &,- 2195 &, 1030 \\
\hline
\end{tabular}

Based on the estimation results in Table 1, we can see whether there is a mediating effect or not. Through the output of the indirect effect section, it can be seen that the elasticity coefficient value of Third-Party Funds is -0.2513 with the Confidence Interval (CI) value from 
the Bootstrap for Lower Level for CI (LLCI) of -0.7041 and Bootstrap for Upper Level for CI ( LLCI) of 0.2974. According to Hayes, if the range of BootLLCI and BootULCI values does not include zero (0), it can be concluded that there is a significant effect, or a mediating effect occurs [33]. From the estimation results, the non-standardized bootstrap indirect effect elasticity coefficient is -0.2513 , and the $95 \%$ confidence interval (CI) ranges from -0.7041 to 0.2974 . That is, the value of zero $(0)$ is included in the range of the confidence interval. So it can be concluded that the indirect effect of third-party funds on profitability through the intermediation function as a mediator is not significant. Or in other words, financing distribution activities as an intermediary function have not been able to mediate between Third-Party Funds on the Bank's ability to generate profits.

Furthermore, the estimation results for the indirect effect of non-performing financing on profitability. Through the output of the estimation of the indirect effect section, it can be seen that the elasticity coefficient value of non-performing financing is -0.0789 with the Confidence Interval (CI) value from the Bootstrap for Lower Level for CI (LLCI) of - -0.2195 and Bootstrap for Upper Level for CI. (LLCI) of 0.1030. From these results, the value of the indirect effect elasticity coefficient is not standardized by a bootstrap of -0.0789 , and the $95 \%$ confidence interval (CI) ranges from -0.2195 to 0.1030 . So it can be concluded that the indirect effect of non-performing financing on profitability through the intermediation function as a mediator is also not significant. Or in other words, financing distribution activities as an intermediary function have not been able to mediate between problematic financing and the Bank's ability to generate profits. The results of this study do not support the hypothesis but strengthen the results of a study by Setiawan and Indriani, which states that based on path analysis it is known that financing cannot mediate the effect of Third-Party Funds and non-performing financing on profitability [16].

\section{Conclusion}

Third-Party Funds (TPF) have a significant direct effect on the Intermediation Function, with a negative relationship direction. This means that the increase in third-party funds is not directly proportional to the increase in financing as a function of bank intermediation, or on the contrary, it decreases. Troubled financing has a significant direct effect on the Intermediation Function, also with a negative relationship direction. This means that an increase in the ratio of non-performing financing will result in a significant decrease in the financing ratio or the bank's intermediation function. Intermediation function directly does not have a significant effect on profitability, with a positive relationship direction. This means that, on average, during the research period, financing activities as a bank intermediation function have the potential to increase profits, but not significantly.

Third-Party Funds (TPF) have a direct significant effect on profitability, with a positive relationship direction. This means that an increase in third-party funds contributes significantly to creating profits for the bank. Meanwhile, non-performing financing has a direct and significant negative effect on profitability. This means that an increase in the ratio of nonperforming financing results in a significant decrease in bank profitability. The estimation result of the transmission line between Third-Party Funds (TPF) and non-performing financing on profitability, through the intermediation function as moderator, is not significant. This means that financing as a bank intermediation function cannot mediate the effect of Third-Party Funds (TPF) and non-performing financing on profitability. 


\subsection{Implications}

The results of the study show that the intermediation function and the level of profitability of Islamic Commercial Banks in Indonesia, during the study period are directly determined by the volatility of non-performing financing and the development of third-party funds. This condition requires the banking industry to intensively implement policies to maintain the quality of financing by applying the precautionary principle to reduce the rate of non-performing financing, and also to continue to strive to maintain the quality of financing and other productive assets.

\section{References}

[1] B. Biagio, "What Makes Banks Special? A Study of Banking, Finance, and Economic Development," Policy Res. Work. Pap., doi: https://doi.org/10.1596/1813-9450-2408.

[2] R. Masumbuko, F. Kerongo, and M. Wafula, "Effects of financial intermediation of microfinance institutions on financial sector development," Int. J. Soc. Sci. Entrep., vol. 1, no. 13, pp. 386-99, 2014. [3] H. Muharam, "Analisis perbandingan efisiensi bank syariah di Indonesia dengan metode data envelopment analysis (Periode tahun 2005)," J. Ekon. dan Bisnis Islam, vol. 2, no. 3, pp. 80-166, 2007. [4] R. Siringoringo, "Analisis Fungsi Intermediasi Perbankan Indonesia (Studi Kasus Bank Umum Konvensional yang Tercatat di BEI Periode 2012-2016)," J. Inspirasi Bisnis dan Manaj., vol. 1, no. 2, pp. 135-44, 2017.

[5] N. Sunaendy and L. Fadhilah, "Syariah Bank Financing," no. 90855, [Online]. Available: https://mpra.ub.uni-muenchen.de/90855/ MPRA.

[6] M. Augustinus Sipatuhar, Persoalan-persoalan Perbankan Indonesia. Jakarta: Gorga media, 2007.

[7] SK DIR BI Nomor: 30/21/KEP/DIR, tata cara penilaian tingkat kesehatan bank. 2017.

[8] Surat Edaran Bank Indonesia No. 13/24/DPNP, Penilaian Tingkat Kesehatan Bank Umum. 2011.

[9] F. A. Yuwono and W. Meiranto, "Analisis Pengaruh Dana Pihak Ketiga, Loan To Deposit Ratio, Capital Adequacy Ratio, Non Performing Loan, Return On Assets, Dan Sertifikat Bank Indonesia Terhadap Jumlah Penyaluran Kredit (Studi Empiris: bank yang terdaftar di BEI),” 2012.

[10] L. Fitri, Y. Maulida, and T. Indrawati, "Pengaruh Suku Bunga Kredit, Dana Pihak Ketiga (DPK), dan Giro Wajib Minimum Terhadap Penyaluran Kredit Pada PT. Bank Central Asia, TBK. di Indonesia Tahun 2001-2015," Riau University, 2017.

[11] W. L. Oka, Komang, I. G. A. Purnamawati, and N. K. Sinarwati, Pengaruh Dana Pihak Ketiga, Penilaian 5C Kredit dan Kualitas Kredit Terhadap Keputusan Pemberian Kredit di PT Bank Pembangunan Daerah Bali Cabang Singaraja. Singaraja: e-Journal S1 Ak Universitas Pendidikan Ganesha, 2015.

[12] Yuliana, "Pengaruh Risiko Pembiayaan Murabahah dan Tingkat Suku Bunga Kredit terhadap Margin Murabahah,” Universitas Pajajaran, Bandung, 2012.

[13] Y. F. Somantri and W. Sukmana, "Analisis Faktor-Faktor yang Mempengaruhi Financing to Deposit Ratio (FDR) pada Bank Umum Syariah di Indonesia," Berk. Akunt. dan Keuang. Indones., vol. 4, no. 2, pp. 61-71, 2019.

[14] Efrina and A. A. Sari, "Pengaruh Dana Pihak Ketiga, NPF, CAR, Terhadap Tingkat Likuiditas (FDR)," Manag. Anal. J., vol. 5, no. 1, 2016.

[15] M. Almunawwaroh and R. Marliana, "Pengaruh CAR, NPF dan FDR terhadap profitabilitas bank syariah di Indonesia," Amwaluna J. Ekon. Dan Keuang. Syariah, vol. 2, no. 1, pp. 1-17, 2018.

[16] U. N. A. Setiawan and A. Indriani, "Pengaruh Dana Pihak Ketiga (DPK), Capital Adequacy Ratio (CAR), dan Non Performing Financing (NPF) terhadap Profitabilitas Bank Syariah dengan Pembiayaan sebagai Variabel Intervening,” Diponegoro J. Manag., vol. 5, no. 4, pp. 121-131, 2016.

[17] V. Rivai and A. P. Veithzal, Islamic Financial Management. Jakarta: Raja Grafindo Persada, 2008. [18] Hery, Analisis Laporan Keuangan: Integrated and Comprehensive Edition. Jakarta: PT Gramedia Widiasarana Indonesia, 2016. 
[19] Peraturan Bank Indonesia Nomor 911/PBI/2007, Sistem Penilaian Tingkat Kesehatan Bank Umum Berdasarkan Prinsip Syariah dan Surat Edaran Bank Indonesia Nomor 9/24/DPbS Tanggal 30 Oktober 2007. 2007.

[20] A. R. Fadhilah and N. Suprayogi, "Pengaruh Fdr, NPF dan Bopo terhadap Roa Perbankan Syariah di Indonesia," J. Ekon. Syariah Teor. dan Terap., vol. 6, no. 12, pp. 2369-80, 2019.

[21] I. Ghozali, "Aplikasi Analisis Multivariate dengan Program IBM SPSS 21 Update PLS Regresi," 2013.

[22] F. Astuti, "Pengaruh Efisiensi Usaha, Risiko Keuangan dan Kepercayaan Masyarakat terhadap Kemampuan Penyaluran Pembiayaan pada Bank Umum Syariah di indonesia Tahun 2011-2014,”J. Ekon. Keuang. Islam, vol. 02, no. 2, 2016.

[23] "Harmonisasi Fungsi Intermediasi Perbankan." https://feb.ub.ac.id/harmonisasi-fungsiintermediasi-perbankan.html.

[24] "Selama Pandemi, Pertumbuhan Kredit Perbankan Melambat Dan Dpk Naik." https://www.merdeka.com/uang/selama-pandemi-pertumbuhan-kredit-perbankan-melambat-dan-dpknaik.html.

[25] "BI: Fungsi Intermediasi Sektor Keuangan Masih Lemah." https://www.medcom.id/ekonomi/keuangan/yKXA0A9N-bi-fungsi-intermediasi-sektor-keuanganmasih-lemah.

[26] N. Sari and N. Murni, "Analysis of the effect of third party fund, capital adequacy ratio, and loan to deposit ratio on bankes profitability after the application of IFRS," Indones. Account. Rev., vol. 6, 2017, doi: https://doi.org/10.14414/tiar.v6i1.855.

[27] P. A. Ardheta and H. R. Sina, "Pengaruh Capital Adequacy Ratio, Dana Pihak Ketiga, Non Performing Financing Dan Pembiayaan Murabahah Terhadap Profitabilitas," J. Akunt. dan Manaj., vol. 17, no. 02, pp. 32-38, 2020.

[28] U. Dawood, "Factors impacting the profitability of commercial banks in Pakistan for the period of (2009-2012),” Int. J. Sci. Res. Publ., vol. 4, no. 3, pp. 1-7, 2014.

[29] M. Y. Wibisono and S. Wahyuni, "Pengaruh Car, Npf, Bopo, Fdr, Terhadap Roa Yang Dimediasi Oleh Nom,” J. Bisnis dan Manaj. (Journal Bus. Manag., vol. 17, no. 1, pp. 41-62, 2017.

[30] H. P. Dewi and Y. N. Sari, "Analisis Pertanggungjawaban Keuangan Organisasi Nirlaba dan Penyusunan Laporan Keuangan Sesuai dengan PSAK 45 di Masjid Al-Muttaqin Bekasi," J. Manaj. Bisnis Krisnadwipayana, vol. 6, no. 3, 2018.

[31] A. B. Rachmat and E. Komariah, "Faktor-Faktor Yang Mempengaruhi Profitabilitas Pada Bank Umum Syariah Periode 2010-2015,” J. Online Insa. Akuntan, vol. 2, no. 1, pp. 17-34, 2017.

[32] Ubaidillah, "Pembiayaan Bermasalah pada Bank Syariah: Strategi Penanganan dan Penyelesaian," el-JIZYA, vol. 6, no. 2, 2018.

[33] A. F. Hayes, Introduction to Mediation, Moderation, and Conditional Process Analysis: A Regression-Based Approach. New York, NY: The Guilford Press - Bolin - 2014 - Journal of Educational Measurement - Wiley Online Library. NY: The Guilford Press, 2013. 